\title{
Why surveyors should not get hung up on case law
}

Received (in revised form): 4 th July, 2005

\section{Vivien King}

is a solicitor and consultant to law firm Bond Pearce. She is an Honorary Member of the RICS, a PACT Arbitrator and a Fellow of the Continuing Professional Foundation. She writes articles and lectures nationwide on all aspects of property law.

\begin{abstract}
It is thought by many that unless judges' words are quoted (or even misquoted), a speaker knows little about their chosen topic. How wrong they can be! This paper looks at how judges give their decisions based upon the very particular and often narrow facts presented to them. With particular reference to the law (and facts) relating to dilapidations, it shows how a building surveyor, for instance, can mislead himself by knowing only the outcome of a case and not the full facts in the context of which the judgment was given. A little knowledge is a dangerous thing. The words of a judge, of course, can clarify matters and give guidance to practitioners. This paper quotes one judge who reminds readers that keeping in repair does not mean perfect repair and another who underlines the fact that judges 'are ordinary speakers of English'. To quote a few words out of context and without distinguishing the facts in the quoted case from those in the one in which the adviser is involved is, at best, misleading and, at worst, can leave the client poorly advised.
\end{abstract}

So, before deciding that a practitioner must be knowledgeable because he can quote a judge or two, read this paper.

\section{Keywords:}

determining facts, dilapidations, case law, judicial decisions, lease covenants, meaning and context of words

\section{INTRODUCTION}

Despite the best endeavours of politicians, both in the UK and in Europe, the people of the UK are not subject to a written constitution (Oliver Cromwell tried but failed). The UK is not even subject to a single legal system but to several (for instance, the law in England and Wales differs substantially from that in Scotland or even from that administered in the Isle of Man). The relevant law is found, however, by consulting parliamentary statutes and the decisions of judges sitting in the courts within a particular region who comment, against the background of the facts of the case before them, upon the statutes and the law which has built up from long usage, the reasoning for which is often lost in time (the 'common law').

In attempting to ascertain what the law says about a topic within one's particular jurisdiction (in this case, England and Wales), one is best 


\section{Consult textbooks and} statute law

\section{Distinguish one case from another}

Take for example a roof advised to consult with a good, relevant, up-to-date textbook and the statute law. But there are many who believe that unless they are able to quote (or, it has to be said, often misquote) the words of some learned judge they cannot be thought of as understanding any particular topic.

Without meaning to pick on them in particular, but merely to quote one example from numerous examples, building surveyors considering their advice on dilapidations will often rush to give details of one reported case which has some connection with the facts before them and rely upon that before they consult the lease before them or examine the building for disrepair. They, and many, many others like them, are totally 'hooked on case law'. Here is a plea not to be!

\section{JUDGES' DECISIONS}

A judge will come to his decision from the very particular and often very narrow facts placed before him and from the law presented to him by the legal advocates, who have a duty to refer to all relevant law, distinguishing their case from those presented where appropriate. It is extremely unlikely that those exact same facts will arise again and hence it is reasonably easy to distinguish one case from another.

Taking again the example of dilapidations, the wording of the particular lease under consideration, the nature of the disrepair at the premises and the works required to rectify that disrepair will never match the lease, disrepair and required works in the case upon which the judge commented. Hence, for any party or adviser to rely upon a decision in one particular case to support their argument in another is, to say the very least, 'risky'.

Having said that, judges' decisions should not and cannot be ignored. They are part of the law of a country and need to be consulted; however, the consultants should understand the information with which they are dealing and use it with considerable care. The old maxim that 'a little knowledge is a dangerous thing' could not be more relevant than in this context.

\section{AN EXAMPLE}

Taking, for instance (and continuing the theme of dilapidations), a roof which, the landlord claims, should have been replaced by the tenant before its lease came to an end. The works are to be included in a terminal schedule of dilapidations.

First, of course, the roof must fall within the tenant's covenant to repair within the lease in question. This will require reference to, at the very least, the description of the demised premises and the covenant to repair. While legal interpretation may be required, usually it will be a question of fact whether or not the roof is the tenant's liability under the terms of the lease.

One then has to determine whether there has been physical deterioration of the roof (ie there is some disrepair) which will bring it below the standard of repair contemplated by the covenant. It will be a question of fact, not law, as to whether the roof is out of repair. There are no definitive rules for ascertaining the 'standard of repair' — it will depend 


\section{Facts are most} important

\section{Facts will differ from those in reported cases}

upon the wording of the lease. For instance, the general words 'to keep in repair' differ from 'to keep in good and substantial repair and condition'. Legal interpretation again may be required but the lawyer's advice will not alter the wording of the covenant or the standard of repair to be adopted. 'Words' are looked at later in this paper.

Having ascertained that there is disrepair for which the tenant is liable and that the physical state of the roof has deteriorated and is below the contemplated standard of repair in the lease, one then has to determine what works are needed to put the roof back into the required physical state. It may be that 'patch' repairs are possible or, if patching is not possible, the deterioration may be so extensive that only complete replacement is feasible. This determination will be a question of fact and not, generally speaking, of the law.

The above questions of fact will be determined and recorded by a building surveyor who will examine the lease and the building. In giving his professional view, he should be uninfluenced by the party instructing him. Furthermore, it is only if there is uncertainty as to the meaning and effect of the words used in the covenant, against the background of the recorded facts, that reference to the law is required. The facts are by far the most important matter in these early stages of the case.

Despite the above situation, upon being instructed by the landlord to prepare a schedule of dilapidations for which the tenant is liable, the building surveyor in this example prepares a schedule of wants of repair for the building in question with little or no regard to the tenant's liability under the lease. He records that the roof is out of repair and, without considering patching (or even if the tenant has a liability), knowing his client wants the tenant to replace the roof, turns immediately to the case law to assist his by now poorly advised client.

The surveyor recalls two reported cases and refers to them as the authority for advising that his client's tenant must replace the roof. Furthermore, he advises that the tenant must do the works using the highest quality materials, higher than those previously used, regardless of the cost, again quoting the two cases as his authority. In giving his advice, he does not consider the facts recorded in the reported cases. If he had done so, he probably would have found that they (ie the wording of the lease, the disrepair and the proposed works including the cost of the required materials) differ completely from those in his client's case. In that context, the cases are substantially irrelevant.

The two cases he has in mind are Elite Investments Ltd $v$ TI Bainbridge (Silencers) Limited [1986] 2 EGLR 43 and Postel Properties Limited v Boots the Chemist [1996] 2 EGLR 60.

\section{The Elite and Postel cases and other stories}

The Elite case involved a steel-framed industrial building constructed in 1940. It had a metal truss pitched roof covered with corrugated, galvanised steel sheets to which, as the galvanising wore off and corroding commenced, a bituminous coating had been applied. The building was divided into three units and all three leases were considered. This note relates to a terminal schedule of dilapidations served pursuant to one 
Roof beyond patching

\section{Renewal a matter of judgment}

lease. The unit was leased in June 1977 for a term expiring in October 1984. The tenant had covenants to 'repair replace clean paint maintain mend and keep the demised premises' (which specifically included the roof) and 'so painted repaired replaced cleansed maintained amended and kept as aforesaid at the expiration or sooner determination of the term quietly to yield up'.

When the lease was granted, the roof was far from perfect but still capable of being repaired. By October 1984, however, the roof was beyond patching and needed complete replacement. The landlord proposed that the material to be used should be polyvinyl chloride coated corrugated steel sheeting because it was lighter than the original galvanised steel and, reportedly, virtually maintenance free. The new roof would also be insulated. The cost of these proposed works was similar to that which would have been incurred if a new galvanised steel roof with bituminous coating had been applied.

The judge held that, while the landlord's proposed roofing material was new, its use was 'just taking advantage of better materials that are now on the market' and, while the older type of materials were still available, the job 'costs the same'. He concluded that replacement of the roof using the new materials did fall within the tenant's repairing covenant.

The Postel case was a service charge case in respect of a large shopping centre. The landlord covenanted "with all due diligence to keep the... roofs of the demised premises in the Shopping Centre in good and substantial repair and condition'. The cost of so doing was recoverable as part of the service charge.

The judge commented: 'Clearly it is a matter for experienced judgment when the time has come to renew a roof'. The landlord's surveyor concluded that, having surveyed the roof, the point had been reached when phased replacement was more economical than continuing with patch repairs. The proposed replacement roof was of a different specification from that originally used but the judge found that the works were "such as a reasonably minded building owner might undertake and they do not amount to giving back to the landlord something different from that which existed before'. He concluded that the landlord could recover the costs.

In both cases, the judges heard detailed evidence and reached their conclusions on the very particular facts presented to them. The cases are not authority for stating that any roof out of repair can be replaced or that new or higher specification materials always can be used; to hear some advisers, however, one would think that they are. Their logic, even were it soundly based, would flounder in any event when one considers cases in which repair, not replacement, is held by the judiciary to be appropriate. Such an example may be seen in the case of Riverside Property Investments Ltd v Blackhawk Automotive [2005] 01 EG 94.

In the Riverside case, the tenant covenanted to repair its light industrial unit 'well and substantially' during the term and to yield it up 'in good and substantial repair and condition in accordance with the covenants hereinbefore contained' at the end of the term. The unit's roof consisted of asbestos cement sheets incorporating translucent roof lights and roof 


\section{Repair a perfectly viable option}

fasteners of the bolt-hook variety. Immediately prior to the end of the lease, the tenant carried out extensive repairs and replaced the roof lights and the fixings with 'topfix' fasteners. Subsequently, the landlord replaced the whole of the roof and sought the cost of so doing from its ex-tenant, claiming breach of the yielding up covenant. The court held on the evidence that repair was a perfectly viable option. Replacement was only required if repair was not reasonably or sensibly possible. If the covenant could be performed properly in one of two ways (repair or replacement) then the tenant could not be criticised for choosing the least expensive option. The decision to use topfix fasteners could not be criticised and the continued presence of asbestos in the original roof sheets could not be a reason to contend that the defendant had breached its repairing covenant. Again, this case, like the Elite and Postel cases, was decided upon its facts.

\section{WORDS - THEIR MEANING AND CONTEXT}

Of course it would be wrong if one were to conclude that the words of the judiciary should never be consulted. There are numerous instances where the judges' guidance gives the very foundation to UK law.

One example that leaps to mind relates to the phrase "such consent not to be unreasonably withheld' in the context of tenants' covenants and applications to the landlord to assign or sublet. In the case of International Drilling Fluids v Louisville Investments (Uxbridge) [1986] Ch 513, the Court of Appeal laid down the general guidelines when considering the court's approach to reasonableness and, while these guidelines had to be updated following the passing of the Landlord and Tenant Act 1988 (and were updated by Miller LJ in Kened Limited and another $v$ Connie Investments Limited [1997] 1 EGLR 21), they still form the very foundation of much legal advice given.

Equally, on occasions, judges do clarify the law. Before the Court of Appeal gave its judgment in Jervis v Harris [1996] 10 EG 159, it was not clear whether lease clauses enabling a landlord to enter demised premises and carry out repair works in default of the tenant allowed the landlord to recover the costs incurred as damages (thus bringing into play all the limitations associated therewith) or as a debt. As is now known, costs are recoverable as a debt.

Judges also may underline a common-sense approach to words and it is useful to know of their approach. For instance, His Honour Judge Rich QC (sitting as a High Court Judge) said 'good and substantial repair does not, in my judgment mean pristine condition or even perfect repair' (see Commercial Union Life Assurance Co Ltd v Label Ink Ltd [2001] L\&TR 29). Now that really is useful guidance to any practitioner.

Generally speaking, however, one must understand the context in which judgments are given. Take the words uttered by the judge out of context and they have little, if any, relevance to another set of facts. For example, it always has been considered almost impossible to obtain a mandatory injunction to force a tenant to comply with its covenant to repair. But in the case of Rainbow Estates Limited $v$ Tokenhold Limited and another 


\section{Limited meaning of judge's words}

\section{"Repair" is an ordinary \\ English word}

[1998] 24 EG 1213, Mr Lawrence Collins QC (sitting as a High Court Judge) said the following.

'In my judgment, a modern law of remedies requires specific performance of a tenant's repairing covenant to be available in appropriate circumstances, and there are no constraints of principle or binding authority against the availability of the remedy.'

Reading those words out of their context, one would think that the remedy of specific performance would be frequently considered appropriate. When one considers the facts of the case, however (there was no forfeiture covenant in the lease, the landlord had not reserved to itself the right to go into the property to carry out repairs if the tenant failed to comply with its covenant and the landlord had been served with a notice to repair by the local authority as the premises were listed), one suddenly realises the very limited meaning of the words used by the judge 'in appropriate circumstances'.

One should also remember that some words do have a very particular legal meaning. Take, for instance, the phrase 'competent landlord' which has a very particular meaning within the context of Part II of the Landlord and Tenant Act 1954 (which is ascertained from studying the statute itself, not the case law). But most are ordinary English words and should be looked at as such. In Post Office v Aquarius Properties Limited [1985] 2 EGLR 105 , Hoffman J (as he then was), in considering the word 'repair', said the following.

\footnotetext{
"The whole law on the subject may be summed up in the proposition that "repair" is an ordinary English word ... in the end ... the question is whether the ordinary speaker of English would consider that the word "repair" as used in the covenant was appropriate to describe the work which has to be done. The cases do no more than illustrate specific contexts in which judges, as ordinary speakers of English, have thought that it was or was not appropriate to do so.'
}

Try to make the word 'repair' mean something other than what it is understood to mean in any context outside the legal documentation one is considering and muddles arise.

\section{CONCLUSIONS}

Cases turn on their facts Cases turn on their facts and each set will rarely match those in another case. So can anything at all be gleaned from the words of judges? Yes of course it can. Judges give guidance and clarification to the law and, on occasions, underline the need for good, old-fashioned common sense. It is useful to know how the judges might approach a problem arising from the case in which one is involved, should it end up in the courtroom. But it is the facts of the case that are important. Concentrate upon them and the answer to the case often will be obvious without the need for judicial consideration. Concentrate upon a judicial decision given in the context of another set of facts and only confusion can arise. 